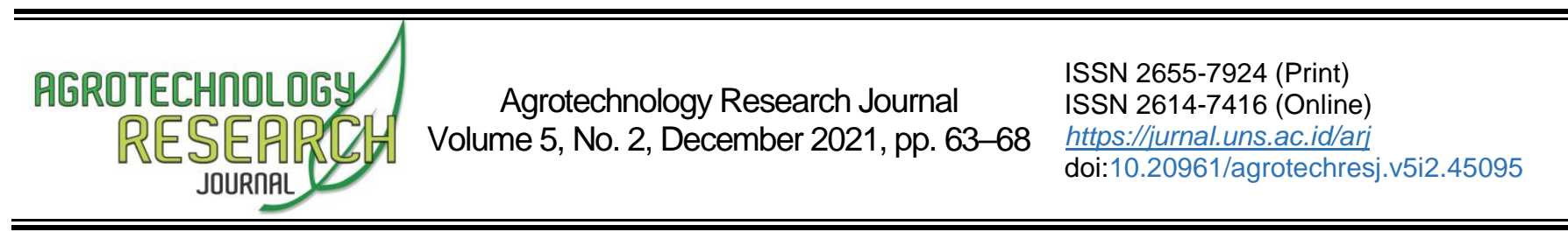

\title{
Keragaan beberapa Varietas Sorgum terhadap Aplikasi Kitosan Iradiasi
}

\section{Performance of several Varieties of Sorghum against Irradiated Chitosan Applications}

\author{
Ferdifta Wahyu Anggita ${ }^{1 *}$, Puji Harsono ${ }^{2 *}$, Retno Wijayanti ${ }^{3}$, Supriyono ${ }^{4}$ \\ ${ }^{1-4}$ Faculty of Agriculture, Universitas Sebelas Maret, Surakarta, Jawa Tengah 57126, Indonesia
}

Received 21 October 2020; Accepted 05 January 2021; Published 31 December 2021

\begin{abstract}
Sorghum is a versatile, drought-resistant cereal crop. Increasing sorghum production needs special attention, although Indonesia has the potential for sorghum development. Irradiated chitosan can be used as a plant growth promoter and organic fertilizer to improve the performance of sorghum. This study aims to provide recommendations for sorghum varieties that are suitable for development and planting in dry land and are known to be able to control pests organically with the application of chitosan irradiation with optimum concentration. The experimental design was a separate plot with sorghum varieties (Numbu, Keller, and Kawali) as the main plot and the irradiated concentrations of chitosan (without irradiation, 2, 4, and $6 \mathrm{ml}^{-\mathrm{L}^{-1}}$ ) as subplots. The results showed that the sorghum variety and the optimum chitosan irradiation concentration of 2.76 and $5.15 \mathrm{ml}^{-\mathrm{L}^{-1}}$ increased the dry weight of stover per plant by $93.04 \mathrm{~g}$ per plant and increased the sugar content of sorghum with Brix $15.03 \%$. The varieties of Numbu, Keller, and Kawali significantly affected plant height, number of leaves, weight of 100 seeds, and plant fresh weight per plot or forage of sorghum.
\end{abstract}

Keywords: legume; parasitoid; predator; Sorghum bicolor

Cite This As (CSE Style): Anggita FW, Harsono P, Wijayanti R, Supriyono. 2021. Keragaan beberapa varietas sorgum terhadap aplikasi kitosan iradiasi. Agrotechnology Res J. 5(2): 63-68. https://doi.org/10.20961/agrotechresj.v5i2.45095.

\section{PENDAHULUAN}

Sorgum (Sorghum bicolor L. Moench) merupakan tanaman serealia yang memiliki daya adaptasi agroekologi luas (Umar 2017) dan tahan terhadap kekeringan (Rumambi et al. 2018). Indonesia merupakan salah satu negara yang berpeluang dalam pengembangan sorgum dengan sistem usaha terintegrasi sebab lahan kering belum dimanfaatkan secara optimal masih luas (Rahayu et al. 2017). Pengembangan sorgum di Indonesia masih menghadapi sejumlah kendala baik teknis maupun sosial ekonomi. Selain itu, pemerintah juga belum menempatkan sorgum sebagai prioritas dalam program perluasan areal tanam dengan alasan sorgum bukan kebutuhan pokok (Direktorat Budidaya Serealia 2013). Kendala lain pengembangan sorgum di Indonesia adalah ketersediaan varietas unggul sorgum dan minat masyarakat untuk budidaya sorgum relatif rendah (Arief et al. 2013). Manfaat dari sorgum sangat besar, bijinya sebagai bahan pangan dan pakan ternak, hijauan sorgum sebagai bahan pakan ruminansia dan nira batang sorgum digunakan sebagai bioetanol. Varietas Numbu, Keller dan Kawali merupakan varietas unggul

${ }^{*}$ Corresponding Author:

E-Mail' : ferdiftaanggita@gmail.com

E-mair:pharsono61@gmail.com hasil introduksi yang memiliki adaptasi tinggi pada lahan kering. Singgih (2002) menyatakan bahwa Varietas Numbu dan Kawali dilepas pada tahun 2001 dan beradaptasi baik pada lahan kering masam, hasil 4 - 5 ton.ha-1.

Penanaman sorgum pada lahan kering disesuaikan dengan varietas pada lingkungan curah hujan terbatas dan serta toleran terhadap hama dan penyakit (Marles et al. 2018). Oleh karena itu, perlu didapatkan varietas yang tepat untuk dikembangkan di lahan kering guna menunjang pertumbuhan dan peningkatan produksi. Salah satu upaya untuk mempercepat pertumbuhan dan meningkatkan keragaan sorgum yaitu dengan aplikasi zat pengatur tumbuh kitosan iradiasi. Zat pengatur tumbuh (ZPT) kitosan iradiasi berasal dari pemanfaatan kulit udang yang diproses dengan radiasi gamma dan berkas elektron bersumber dari Co-60 kaya akan asam amino serta plant growth promoter seperti IAA, giberelin dan sitokinin. Manfaat kitosan iradiasi antara lain dapat meningkatkan pertumbuhan tanaman, mencegah penyakit tanaman dan meningkatkan imunitas serta produktivitas tanaman (Evani 2015). Pemberian kitosan hingga konsentrasi $4 \mathrm{ccl} / \mathrm{L}$ air terhadap tanaman stroberi menunjukkan hasil yang positif terhadap peningkatan tinggi tanaman, jumlah daun dan bobot kering tanaman (Abdel-Mawgoud 2010).

Berdasarkan hal tersebut maka perlu dilakukan penelitian ini untuk mengetahui varietas sorgum yang 
cocok dikembangkan dan mengetahui konsentrasi optimum kitosan iradiasi yang berfungsi sebagai Zat Pengatur Tumbuh dan pengendalian hama secara organik.

\section{BAHAN DAN METODE}

Penelitian dilaksanakan pada bulan April-Agustus 2019 di Desa Tangeran, Kecamatan Nguter, Kabupaten Sukoharjo, Jawa Tengah (110 $57^{\prime} 33.70^{\prime \prime}$ BT - $110^{\circ} 42$ 6.79" BT dan antara $7^{\circ} 32^{\prime} 17.00^{\prime \prime}$ LS - $7^{\circ} 49^{\prime} 32.00^{\prime \prime}$ LS) dengan jenis tanah Vertisol. Bahan tanam adalah benih sorgum Varietas Numbu, Keller dan Kawali, serta Kitosan Iradiasi. Percobaan menggunakan Rancangan Petak Terpisah (split plot) dalam Rancangan Acak Kelompok Lengkap 3 × 4 faktor. Dua belas kombinasi perlakuan diulang 3 kali dengan petak utama (main plot) yaitu varietas sorgum (Numbu, Keller, dan Kawali) dan anak petak (sub plot) yaitu konsentrasi Kitosan Iradiasi (tanpa kitosan, 2, 4, dan $6 \mathrm{ml}^{-L^{-1}}$ air). Variabel pengamatan meliputi tinggi tanaman dan jumlah daun pada umur 6 minggu setelah tanam (MST), luas daun (metode gravimetri), diameter batang (menggunakan jangka sorong), bobot segar brangkasan per tanaman dan per petak, bobot kering brangkasan per tanaman (menggunakan timbangan) serta kadar gula batang (Hand refractometer Atago), laju asimilasi bersih (LAB) (menggunakan rumus Wareing dan Phillips 1981) umur berbunga, bobot 100 biji, bobot biji per tanaman dan intensitas kerusakan daun akibat hama (3 MST - 12 MST). Analisis data menggunakan uji $F$ taraf 5 dan $1 \%$. Apabila terdapat beda nyata antar varietas sorgum di lanjutkan dengan uji Beda Nyata Terkecil (BNT) 5\% dan apabila terdapat beda nyata aplikasi kitosan dan interaksi dilanjutkan uji Polinomial Ortogonal (untuk mengetahui konsentrasi optimum kitosan iradiasi).

\section{HASIL DAN PEMBAHASAN}

Berdasarkan hasil penelitian, terjadi interaksi antara penggunaan varietas sorgum dan aplikasi kitosan iradiasi pada pengamatan bobot brangkasan kering dan kadar gula batang sorgum. Berdasarkan hasil uji Polinomial Ortogonal pemberian kitosan iradiasi pada tiga varietas sorgum memberikan pengaruh interaksi terhadap bobot kering brangkasan per tanaman pada 9 MST (Gambar 1).

Respons varietas Keller terhadap peningkatan konsentrasi kitosan iradiasi menunjukkan model linier positif $\left(R^{2}: 0,877\right)$ pada bobot kering brangkasan sorgum. Hal itu menunjukkan bahwa semakin tinggi konsentrasi kitosan iradiasi yang diberikan maka semakin besar pula bobot kering brangkasan sorgum yang dihasilkan. Konsentrasi kitosan iradiasi yang diberikan pada Varietas Numbu dengan konsentrasi optimum yaitu 2,76 cc. $\mathrm{L}^{-1}$ menghasilkan bobot kering brangkasan per tanaman terbesar yaitu sebesar 97,039 g per tanaman, walaupun hubungan antara pemberian kitosan iradiasi pada tiga varietas sorgum tidak terlalu erat pengaruhnya yang ditunjukkan dengan koefisien korelasi $(r=0,40)$. Hal tersebut serupa dengan penelitian Oktaviani et al. (2014) bahwa Varietas Numbu memiliki akumulasi bahan kering yang lebih besar dibandingkan Varietas Keller. Hasil penelitian Hossain et al. (2013) menyatakan bahwa aplikasi kitosan dengan konsentrasi 500 ppm dapat meningkatkan bobot kering daun teh tertinggi yaitu sekitar 42,29\% lebih tinggi dari kontrol.

Kadar gula batang sangat dipengaruhi oleh jenis sorgum, iklim, umur sorgum, pemupukan dan pengairan. Ketiga varietas sorgum yang digunakan merupakan jenis sorgum manis atau sweet sorghum (Pabendon et al. 2012). Berdasarkan hasil uji Polinomial Ortogonal pemberian kitosan iradiasi pada tiga varietas sorgum memberikan pengaruh interaksi terhadap kadar gula batang sorgum pada umur 9 MST (Gambar 2).

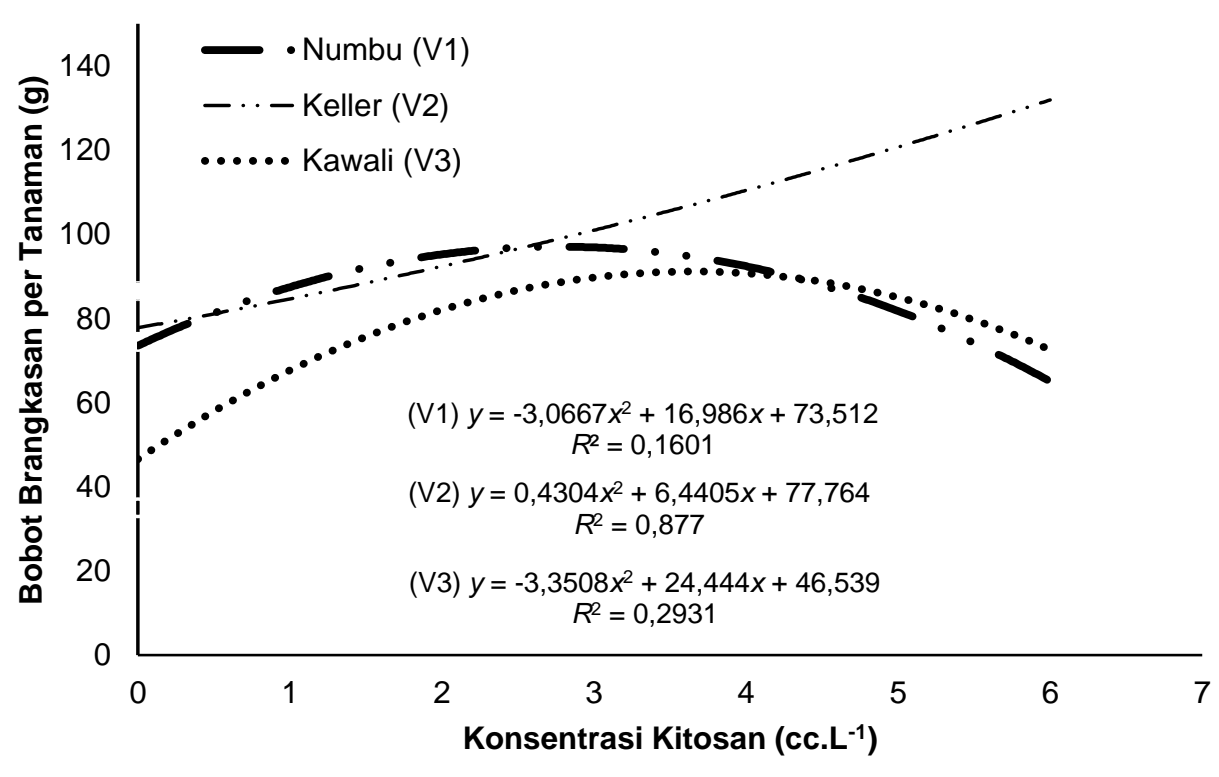

Gambar 1. Regresi hubungan varietas sorgum dan konsentrasi kitosan iradiasi terhadap bobot kering brangkasan per tanaman 


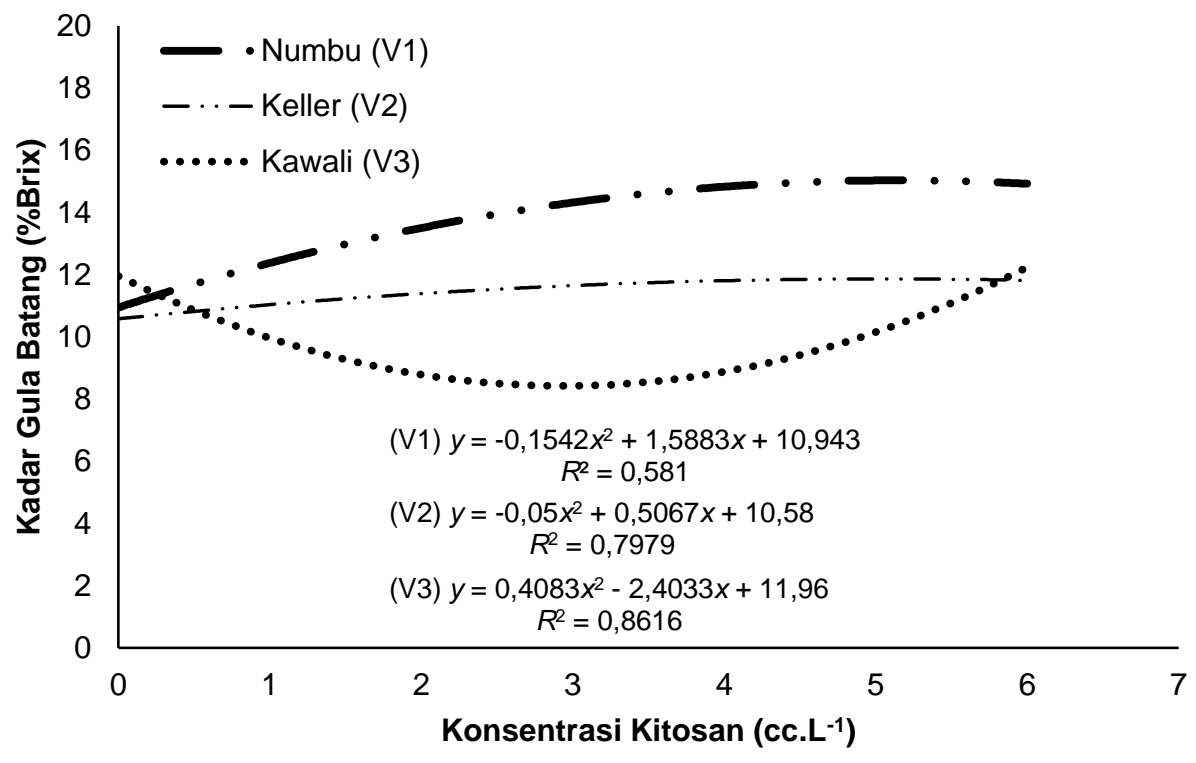

Gambar 2. Hubungan antara beberapa varietas sorgum dan aplikasi kitosan iradiasi terhadap kadar gula batang

Ketiga varietas sorgum yang digunakan dalam penelitian ini merupakan sorgum manis (Sweet sorghum). Konsentrasi kitosan yang diberikan pada Varietas Kawali 6 cc.L-1 pada umur 9 MST menunjukkan respons yang menurun hingga konsentrasi $2,94 \mathrm{cc} . \mathrm{L}^{-1}$. Sedangkan konsentrasi kitosan iradiasi yang diberikan pada Varietas Numbu dengan konsentrasi optimum 5,15 cc. L-1 menghasilkan kadar gula batang sorgum terbesar yaitu sebesar $15,03 \%$ brix dan hubungan antara pemberian kitosan iradiasi pada tiga varietas sorgum memiliki pengaruh hubungan yang erat ditunjukkan dengan koefisien korelasi $(r=0,7)$. Nilai Brix (total soluble solids) nira batang sorgum bergantung pada varietas, lingkungan dan waktu panen tanaman. Hasil penelitian ini serupa dengan penelitian yang dilakukan oleh Wahyuni et al. (2019) bahwa perlakuan kitosan terbukti mempengaruhi derajat brix bulir jagung yang dipanen hingga $7 \%$ dibandingkan kontrol dimana kitosan mampu menginduksi peningkatan sintesis maupun aktivitas enzim-enzim yang terlibat dalam metabolisme gula, seperti Sucrose Phosphate Synthase (SPS) dan fructose 1, 6-2 phosphatase (FBPase).

Varietas berpengaruh nyata terhadap tinggi tanaman, jumlah daun dan bobot segar brangkasan per petak, serta sangat nyata pada bobot 100 biji. Konsentrasi kitosan iradiasi tidak berpengaruh nyata terhadap semua variabel pengamatan. Interaksi sangat nyata antara varietas sorgum dan konsentrasi kitosan iradiasi terdapat pada bobot kering brangkasan per tanaman dan kadar gula batang sorgum (Tabel 1).

Varietas Keller lebih tinggi $18,97 \mathrm{~cm}$ dari Numbu dan 23,31 cm dari Kawali. Varietas Numbu lebih tinggi 4,34 $\mathrm{cm}$ dari Kawali, akan tetapi tidak berbeda nyata (Tabel 1). Hal tersebut sesuai dengan penelitian Hidayat et al. (2018) bahwa Varietas Keller menghasilkan panjang batang tertinggi sebesar $185,13 \mathrm{~cm}$ dan secara nyata lebih panjang daripada Varietas Numbu yang menghasilkan panjang batang 126,62 cm. Hasil ini menunjukkan bahwa secara genetis Varietas Keller mempunyai bentuk morfologi yang lebih besar dibandingkan dengan Varietas Numbu dan Kawali sebab Keller memiliki masa vegetatif lebih lama daripada kedua varietas sorgum yang digunakan.

Tabel 1. Tinggi tanaman, jumlah daun, bobot brangkasan per petak dan bobot 100 biji pada beberapa varietas sorgum

\begin{tabular}{lllll}
\hline Varietas & $\begin{array}{l}\text { Tinggi } \\
\text { tanaman } \\
\text { Sorgum }\end{array}$ & $\begin{array}{l}\text { Jumlah } \\
\text { daun } \\
\text { (helai) }\end{array}$ & $\begin{array}{l}\text { Bobot } \\
\text { brangkasan } \\
\text { segar per } \\
\text { petak }(\mathrm{kg})\end{array}$ & $\begin{array}{l}\text { Bobot } \\
100 \mathrm{biji} \\
(\mathrm{g})\end{array}$ \\
\hline Numbu & $132,57 \mathrm{~b}$ & $9,27 \mathrm{a}$ & $13,37 \mathrm{~b}$ & $3,13 \mathrm{~b}$ \\
Keller & $151,54 \mathrm{a}$ & $9,16 \mathrm{a}$ & $17,79 \mathrm{a}$ & $3,00 \mathrm{c}$ \\
Kawali & $128,23 \mathrm{~b}$ & $8,67 \mathrm{~b}$ & $13,00 \mathrm{~b}$ & $4,18 \mathrm{a}$ \\
\hline
\end{tabular}

Keterangan: Huruf yang sama pada satu kolom menunjukkan tidak berbeda nyata

Varietas Kawali memiliki jumlah daun yang berbeda (lebih sedikit) dengan Numbu dan Keller. Perbedaan tersebut dipengaruhi oleh sifat genetik setiap varietas. Surya dan Hoeman (2008) menjelaskan bahwa banyaknya daun sorgum berkorelasi dengan panjang periode vegetatif, yang dibuktikan dengan setiap penambahan satu helai daun memerlukan waktu 3-4 hari. Varietas Keller memiliki masa vegetatif yang lebih lama dan panjang ruas yang berbeda dibandingkan dengan Varietas Numbu dan Kawali.

Hijauan sorgum dapat dimanfaatkan sebagai pakan ternak ruminansia. Bobot brangkasan segar varietas 
Keller per petak lebih tinggi 4,42 kg daripada Numbu dan $4,79 \mathrm{~kg}$ lebih berat daripada Kawali. Varietas Numbu lebih berat $0,37 \mathrm{~kg}$ dari Kawali akan tetapi tidak nyata (Tabel 1). Hal ini sesuai dengan hasil penelitian Pramanda et al. (2015) bahwa bobot basah terbaik ditunjukkan oleh Varietas Keller. Puspitasari et al. (2012) menjelaskan bahwa beberapa varietas sorgum manis seperti Keller berpotensi dikembangkan sebagai tanaman penghasil hijauan pakan ternak. Budidaya sorgum manis di Indonesia berpotensi untuk memenuhi kebutuhan pakan ternak yang selama ini didominasi oleh pakan impor (Puspitasari et al. 2012).

Bobot 100 biji sorgum varietas Kawali 1,05 g lebih berat daripada Numbu dan 1,18 $\mathrm{g}$ lebih berat daripada Keller (Tabel 1). Bobot 100 biji varietas Numbu 0,13 g lebih berat daripada Keller. Perbedaan bobot biji tanaman sebagai indikasi kualitas biji (lebih besar atau bernas) karena perbedaan asimilat yang disimpan dalam biji. Jabereldar et al. (2017) menyatakan bahwa berat 100 butir sorgum dipengaruhi oleh tekanan air dan genotipe. Bobot rata - rata 100 butir adalah 3,1 g. Stress air pada tahap vegetatif dapat mengakibatkan bobot 100 biji lebih rendah.

Varietas sorgum dan aplikasi kitosan iradiasi tidak berpengaruh nyata terhadap luas daun per tanaman 9 MST, diameter batang, bobot segar brangkasan, laju asimilasi bersih, umur berbunga dan bobot biji pertanaman. Luas daun menjadi parameter laju fotosintesis pertumbuhan per satuan tanaman dalam penerimaan cahaya matahari untuk melakukan proses fotosintesis. Jika luas daun besar berarti jumlah $\mathrm{CO}_{2}$ yang diserap lebih banyak dan proses fotosintesis berjalan lebih baik. Hal ini berbeda dengan hasil penelitian Anggara et al. (2016) bahwa dengan pemberian konsentrasi oligo kitosan 300 ppm dapat meningkatkan luas daun per tanaman jagung srikandi putih. Luas permukaan daun jagung dapat diakibatkan pengaruh dari hormon kinetin dan zeatin yang terkandung dalam oligo kitosan, selain itu penyerapan air oleh sel juga dapat menambah pertambahan ukuran luas daun. Asni et al. (2014) menyatakan bahwa kitosan memiliki kandungan GA, IAA, Zeatin yang mampu mempercepat tumbuhnya tanaman, hasil panennya tinggi, meningkatkan daya tahan tanaman terhadap penyakit, memperpendek masa panen dan meningkatkan kualitas produksi buah, bunga dan sayuran.

Varietas sorgum dan aplikasi kitosan menunjukkan hasil bahwa tidak ada perbedaan nyata terhadap diameter batang pada fase perkembangan sorgum. Hal ini disebabkan pada fase awal pertumbuhan sorgum merupakan musim kemarau dengan curah hujan sangat rendah, sehingga tanaman mengalami stres air yang berpengaruh pada karakteristik pertumbuhannya antara lain diameter batang. De Silva dan De Costa (2004) menyatakan bahwa stres air pada periode awal pertumbuhan berpengaruh negatif terhadap diameter batang pada tanaman tebu.

Bobot segar merupakan indikator yang menunjukkan tingkat serapan air dan unsur hara oleh tanaman untuk metabolisme. Perlakuan varietas sorgum dan aplikasi kitosan tidak berpengaruh nyata terhadap bobot segar brangkasan. Yulisma (2011) menyatakan bahwa semakin tinggi tanaman dan semakin banyak jumlah daunnya, maka bobot segar brangkasan juga akan meningkat. Semakin banyak jumlah daun maka proses fotosintesis yang menghasilkan asimilat akan mempengaruhi bobot segar brangkasan. Penelitian yang dilakukan oleh Islam et al. (2016) menyatakan bahwa aplikasi kitosan dengan konsentrasi 100 ppm pada tahap vegetatif meningkatkan pertumbuhan dan perkembangan tanaman seperti jumlah daun serta dapat direkomendasikan untuk penanaman. Berdasarkan hasil penelitian ini produksi biomassa lebih rendah yang disebabkan curah hujan saat penelitian rendah, mengakibatkan pertumbuhan tanaman yang dimanifestasikan dalam bentuk penurunan produksi biomassa. Jabereldar et al. (2017) menyatakan stres kekeringan merupakan salah satu faktor lingkungan terpenting yang dapat menurunkan pertumbuhan, perkembangan dan produksi sorgum.

Perkembangan luas daun untuk semua perlakuan memberikan respons yang sama. Laju asimilasi bersih dipengaruhi oleh luas daun sorgum. Luas daun tanaman berhubungan dengan kemampuan tanaman melakukan fotosintesis. Capriyati dan Tohari (2014) menyatakan bahwa laju asimilasi bersih tidak konstan terhadap waktu, tetapi menunjukkan suatu kecenderungan penurunan seiring dengan usia tanaman. Kecenderungan usia dipercepat oleh adanya lingkungan yang tidak menguntungkan dan perolehan bobot kering per satuan berat daun menurun dengan bertambahnya daun baru, karena adanya saling menaungi. Tang et al. (2018) menunjukkan bahwa nilai Laju Asimilasi Bersih yang tertinggi terjadi selama periode vegetatif. Secara keseluruhan nilai Laju Asimilasi Bersih akan menurun dengan meningkatnya kerapatan tanaman, semakin tinggi kerapatan tanaman maka semakin rendah nilai $\mathrm{LAB}$ yang diamati di kedua jenis varietas sorgum manis.

Umur berbunga dihitung apabila dalam satu bedeng sorgum telah muncul bunga $50 \%$ dari tanaman per bedeng. Varietas Numbu, Keller dan Kawali mengalami fase pembungaan yang hampir sama. Umur berbunga tanaman lebih dipengaruhi faktor lingkungan terutama oleh intensitas cahaya, curah hujan dan suhu harian. Aplikasi kitosan iradiasi tidak berpengaruh terhadap waktu pembungaan sorgum, hal ini dapat disebabkan karena konsentrasi kitosan yang diaplikasikan pada sorgum yang kurang efektif. Hal ini tidak sesuai dengan pernyataan Asra (2014) bahwa kandungan giberelin yang terdapat pada oligo kitosan atau kitosan iradiasi dapat meningkatkan produksi tanaman. Hormon giberelin dapat merangsang perkembangan bunga dan buah. Faktor lingkungan juga dapat mempengaruhi waktu berbunga tanaman. Alhajturki et al. (2012) menyatakan bahwa pada suhu panas sorgum akan berbunga lebih cepat, dan pada kondisi suhu yang lebih rendah pembungaan sedikit lebih lambat.

Secara morfologi ketiga varietas sorgum manis yang digunakan memiliki panjang malai yang hampir sama, memiliki ukuran biji yang kecil dan bulir biji yang mengisi malai juga sedikit. Irawan et al. (2020) menyatakan bahwa bobot biji berhubungan erat dengan pertumbuhan dan perkembangan tanaman dalam menyerap hara pada masa vegetatif. Apabila pertumbuhan vegetatif tanaman rendah maka pembentukan biji akan 
terhambat. Bila laju fotosintesis tanaman berbeda, maka jumlah asimilat yang dihasilkan juga berbeda, demikian juga dengan bobot biji yang merupakan cerminan dari laju pertumbuhan tanaman.

Hama yang ditemukan pada sorgum terdiri atas hama perusak biji Munia sp. dan Ostrinia furnacalis. Varietas sorgum dengan aplikasi kitosan iradiasi tidak berpengaruh terhadap kedatangan hama. Hidangmayum et al. (2019) menyatakan bahwa kitosan yang diaplikasikan pada daun dapat meningkatkan ketahanan tanaman dengan adanya enzim kitinase yang terkandung pada kitosan yang berhubungan dengan resistensi terhadap patogen.

Kerusakan biji sorgum diakibatkan oleh serangan hama pemakan biji sorgum yaitu burung emprit (Munia sp.) dan ulat penggerek buah sorgum (Ostrinia furnacalis). Menurut Tenrirawe et al. (2013) burung emprit menyukai biji sorgum terutama sorgum manis. Hama Ostrinia furnacalis menyerang malai sorgum dan merusak biji sorgum. Berdasarkan pengamatan malai yang terserang akan tampak berkapur. Perbedaan karakter masing-masing malai sorgum dapat mempengaruhi kedatangan Ostrinia furnacalis dan kerusakan yang diakibatkan oleh hama tersebut. Varietas Numbu (V1) dan Kawali (V3) memiliki sifat dan kerapatan malai kompak sedangkan Varietas Keller (2) memiliki sifat dan kerapatan malai yang lebih longgar. Berdasarkan pengamatan, Varietas Numbu dan Kawali memiliki kerusakan biji lebih besar dan terserang Ostrinia furnacalis lebih tinggi dibandingkan Sorgum Varietas Keller. Nonci et al. (1996) menyatakan bahwa kehilangan hasil akibat 0 . furnacalis mencapai $37,0 \%$ jika tanaman terinfeksi 5 ekor larva pada umur 6 minggu.

\section{KESIMPULAN DAN SARAN \\ Kesimpulan}

Varietas sorgum dan konsentrasi optimum kitosan iradiasi sebesar 2,76 cc.L-1 dan 5,15 cc.Liter ${ }^{-1}$ meningkatkan bobot kering brangkasan per tanaman mencapai 93,039 g dan kadar gula batang hingga $15,03 \%$ Brix. Varietas sorgum berpengaruh nyata meningkatkan tinggi tanaman 6 MST, jumlah daun 6 MST dan hasil bobot 100 biji per tanaman serta bobot segar brangkasan atau hijauan sorgum. Varietas Numbu lebih toleran untuk ditanaman pada lahan kering Sukoharjo dan konsentrasi kitosan iradiasi lebih dari 6 cc.L-1 baik untuk diaplikasikan pada sorgum guna meningkatkan keragaan sorgum.

\section{Saran}

Petani sebaiknya menanam sorgum Varietas Kawali pada lahan setempat sebab dapat dimanfaatkan sebagai hijauan pakan ternak dan biji dapat digunakan sebagai bahan pangan, konsentrasi kitosan iradiasi yang digunakan sebaiknya lebih dari 2 cc liter $^{-1}$ melebihi anjuran pada kemasan guna meningkatkan pertumbuhan dan hasil serta meningkatkan ketahanan sorgum dari hama dan penyakit.

\section{DAFTAR PUSTAKA}

Abdel-Mawgoud AMR. 2010. Growth and yield responses of strawberry plants to chitosan application. Eur J Sci Res. 39(1):170-177.
Alhajturki D, Aljamali M, Kanbar A, Azmah F. 2012. Potential of some sweet sorghum (Sorghum bicolor L.) genotypes under two water regimes for sugar and Bio-ethanol production. Sugar Tech. 14(4):376-382. https://doi.org/10.1007/s12355-012-0181-x.

Anggara R, Sularno S, Junaidi J. 2016. Pengaruh pemberian oligo kitosan terhadap pertumbuhan dan produksi tanaman jagung Srikandi Putih-1. J Agrosains Teknol. 1(2):1-8.

Arief R, Koes F, Komalasari O. 2013. Evaluasi mutu benih sorgum dalam gudang penyimpanan. Dalam: Inovasi teknologi mendukung swasembada jagung dan diversifikasi pangan. Prosiding Seminar Nasional Serealia 2011; 3-4 Oktober 2011; Maros, ID. Maros (ID): Badan Penelitian Tanaman Serealia.

Asni N, Saadilah MA, Saleh D. 2014. Optimalisasi sintesis kitosan dari cangkang kepiting sebagai adsorben logam berat $\mathrm{Pb}$ (II). Spektra J Fis Apl. 15(1):18-25.

Asra R. 2014. Pengaruh hormon giberelin (GA3) terhadap daya kecambah dan vigoritas Calopogonium caeruleum. Biospecies. 7(1):29-33.

Capriyati R, Tohari DK. 2014. Pengaruh jarak tanam dalam tumpangsari sorgum manis (Sorghum bicolor L. Moench) dan dua habitus wijen (Sesamum indicum L.) terhadap pertumbuhan dan hasil. Vegetalika. $3(3): 49-62$.

De Silva ALC, De Costa WAJM. 2004. Varietal variation in growth, physiology and yield of sugarcane under two contrasting water regimes. Trop Agric Res. 16:1-12.

Direktorat Budidaya Serealia. 2013. Kebijakan direktorat jenderal tanaman pangan dalam pengembangan komoditas jagung, sorgum dan gandum. Jakarta: Direktorat Jenderal Tanaman Pangan. Jakarta (ID): Kementan RI.

Evani FS. 2015. Batan Pamerkan Pupuk Hasil Radiasi Nuklir. Jakarta (ID): Arsip Suara Pembaruan; [diakses 12 Maret 2020]. https://www.beritasatu.com/archive/247785/batanpamerkan-pupuk-hasil-radiasi-nuklir.

Hidangmayum A, Dwivedi $P$, Katiyar D, Hemantaranjan A. 2019. Application of chitosan on plant responses with special reference to abiotic stress. Physiol Mol Biol Plants. 25:313-326. https://doi.org/10.1007/s12298-018-0633-1.

Hidayat KF, Sunyoto S, Saputro AD. 2018. Pengaruh kerapatan tanaman dan varietas sorgum terhadap pertumbuhan dan produksi biomassa sorgum pada sistem tumpangsari sorgum dengan ubikayu. Dalam: Prosiding Seminar Nasional Fakultas Pertanian UNS ke 42. Surakarta (ID): Fakultas Pertanian UNS. 2:336-345.

Hossain MA, Hoque MM, Khan MA, Islam JMM, Naher S. 2013. Foliar application of radiation processed chitosan as plant growth promoter and anti-fungal agent on tea plants. Int J Sci Eng Res. 4(8):1693-1698. 
Irawan DZ, Ezward C, Okalia D. 2020. Pengaruh pemberian pupuk kotoran kerbau dan pupuk urea terhadap pertumbuhan dan produksi sorgum (Sorghum bicolor (L.) Moench). J Green Swarnadwipa. 9(1):46-57.

Islam MT, Mondal MMA, Rahman MS, Khanam S, Akter MB, Haque MA, Dafadar NC. 2016. Effect of foliar application of chitosan on growth and yield in tomato, mung bean, maize and rice. Int J Sustain Crop Prod. 11(2):7-17.

Jabereldar AA, El Naim AM, Abdalla AA, Dagash YM. 2017. Effect of water stress on yield and water use efficiency of sorghum (Sorghum bicolor L. Moench) in semi-arid environment. J Agric For. 7(1):1-6.

Marles J, Apriyanto E, Harsono P. 2018. Respon pertumbuhan dan hasil tiga varietas sorgum di lahan pesisir dengan aplikasi bahan organik dan fungi mikoriza arbuskular. Naturalis J Penelit Pengelolaan Sumber Daya Alam Lingkung. 7(1):29-40. https://doi.org/10.31186/naturalis.7.1.9258.

Nonci N, Tandiabang J, Baco D. 1996. Kehilangan hasil oleh penggerek jagung (Ostrinia furnacalis) pada berbagai stadia tanaman jagung. Hasil-Hasil Penelitian Hama dan Penyakit Tanaman Tahun 1996. Maros ID: Balitjas.

Oktaviani D, Hidayat KF, Sunyoto, Kamal M. 2014. Akumulasi bahan kering beberapa varietas sorgum (Sorghum bicolor L.) ratoon I terhadap aplikasi bahan organik pada sorgum pertama. J Kalitbangan 2(3): 69-84.

Pabendon MB, Sarungallo RS, Mas'ud S. 2012. Pemanfaatan nira batang, bagas, dan biji sorgum manis sebagai bahan baku bioetanol. Penelit Pertan Tanam pangan. 31(3):180-187.

Pramanda RP, Hidayat KF, Sunyoto S, Kamal M. 2015. Pengaruh aplikasi bahan organik terhadap pertumbuhan dan hasil beberapa varietas sorgum (Sorghum Bicolor [L] Moench). J Agrotek Trop. 3(1):85-91. https://dx.doi.org/10.23960/jat.v3i1.1960.

Puspitasari G, Kastono D, Waluyo S. 2012. Pertumbuhan dan hasil sorgum manis (Sorghum bicolor (L.) Moench) tanam baru dan ratoon pada jarak tanam berbeda. Vegetalika. 1(4):18-29.
Rahayu M, Samanhudi S, Wartoyo W. 2017. Uji adaptasi beberapa varietas sorgum manis di lahan kering wilayah jawa tengah dan jawa timur. Caraka Tani J Sustain Agric. 27(1):53-62. https://doi.org/10.20961/carakatani.v27i1.14354.

Rumambi, A, Telleng M, Kaunang W. 2018. Produktivitas ratun sorgum varietas kawali dengan pemupukan bokashi feses sapi. Pastura. 7(2): 69-73.

Singgih S, Hamdani M. 2002. Evaluasi daya hasil galur sorgum. Risalah penelitian jagung dan serealia lain. Maros (ID): Balai Penelitian Tanaman Jagung dan Serealia Lain.

Surya MI, Hoeman DS. 2008. Evaluasi keragaman genetik sorgum manis pada mutan generasi Ke-2 hasil iradiasi gamma. Agrivita. 31(2):36-40.

Tang C, Sun C, Du F, Chen F, Ameen A, Fu T, Xie GH. 2018. Effect of plant density on sweet and biomass sorghum production on semiarid marginal land. Sugar Tech. 20:312-322. https://doi.org/10.1007/s12355017-0553-3.

Tenrirawe A, Tandiabang J, Adnan AM, Pabbage MS. 2013. Pengelolaan hama pada tanaman sorgum. Dalam: Sumarno, Damardjati DS, Syam M, Hermanto, editor. Sorgum Inovasi Teknologi dan Pengembangan. Jakarta (ID): IAARD Press. pp. 222-243.

Umar D. 2017. Pertumbuhan dan hasil sorgum di lahan marginal dengan pemberian pupuk kandang domba. Agrivet J IImu Pertan Peternak. 5(1): 7-12.

Wahyuni S, Yusup CA, Eris DD, Putra SM, Mulyatni AS, Siswanto S, Priyono P. 2019. Peningkatan hasil dan penekanan kejadian penyakit pada jagung manis (Zea mays var. Bonanza) dengan pemanfaatan biostimulan berbahan kitosan. E-Journal Menara Perkeb. 87(2):131-139. https://doi.org/10.22302/iribb.jur.mp.v87i2.349.

Wareing PF, Philips IJ. 1981. Growth and differentiation in plant. Third Edition. Oxford (US): Pergamon Press.

Yulisma. 2011. Pertumbuhan dan hasil beberapa varietas jagung pada berbagai jarak tanam. J Penelit Pertan Tanam Pangan. 30(3):196-203. 